\title{
A reliable bioassay procedure to evaluate per os toxicity of Bacillus thuringiensis strains against the rice delphacid, Tagosodes orizicolus (Homoptera: Delphacidae)
}

\author{
Rebeca Mora ${ }^{1}$, Jorge E. Ibarra ${ }^{3} \&$ Ana M. Espinoza ${ }^{1,2}$ \\ 1 Centro de Investigación en Biología Celular y Molecular (CIBCM), Ciudad de la Investigación, Universidad de Costa \\ Rica, San José, Costa Rica; rebemc@gmail.com \\ 2 Escuela de Agronomía, Facultad de Ciencias Agroalimentarias, Universidad de Costa Rica. \\ 3 Departamento de Biotecnología y Bioquímica, CINVESTAV, Irapuato, México.
}

Received 06-XII-2004. Corrected 19-X-2006. Accepted 15-XI-2006.

\begin{abstract}
A reliable bioassay procedure was developed to test ingested Bacillus thuringiensis (Bt) toxins on the rice delphacid Tagosodes orizicolus. Initially, several colonies were established under greenhouse conditions, using rice plants to nurture the insect. For the bioassay, an in vitro feeding system was developed for third to fourth instar nymphs. Insects were fed through Parafilm membranes on sugar (10\% sucrose) and honey bee ( $1: 48 \mathrm{vol} / \mathrm{vol})$ solutions, observing a natural mortality of $10-15 \%$ and $0-5 \%$, respectively. Results were reproducible under controlled conditions during the assay $\left(18 \pm 0.1{ }^{\circ} \mathrm{C}\right.$ at night and $28 \pm 0.1{ }^{\circ} \mathrm{C}$ during the day, $80 \%$ RH and a 12:12 day:light photoperiod). In addition, natural mortality was quantified on insect colonies, collected from three different geographic areas of Costa Rica, with no significant differences between colonies under controlled conditions. Finally, bioassays were performed to evaluate the toxicity of a Bt collection on T. orizicolus. A preliminary sample of twenty-seven $B t$ strains was evaluated on coarse bioassays using three loops of sporulated colonies in $9 \mathrm{ml}$ of liquid diet, the strains that exhibited higher percentages of $T$. orizicolus mortality were further analyzed in bioassays using lyophilized spores and crystals $(1 \mathrm{mg} / \mathrm{ml})$. As a result, strains 26-O-to, 40-X-m, 43S-d and 23-O-to isolated from homopteran insects showed mortalities of 74, 96,44 and $82 \%$ respectively while HD-137, HD-1 and Bti showed 19, 83 and $95 \%$ mortalities. Controls showed mortalities between 0 and $10 \%$ in all bioassays. This is the first report of a reliable bioassay procedure to evaluate per os toxicity for a homopteran species using Bacillus thuringiensis strains. Rev. Biol. Trop. 55 (2): 373-383. Epub 2007 June, 29.
\end{abstract}

Key words: Tagosodes orizicolus, Homoptera, rice delphacid, bioassay, rearing, sugar diet, Bacillus thuringiensis, $\delta$-endotoxins.

The rice delphacid (RDel) Tagosodes orizicolus Muir (Homoptera: Delphacidae) is a monophagous insect pest of rice (Oryza sativa), with a wide distribution in the neotropics of the American continent. RDel is an insect pest of high economic importance not only because it is the vector of the rice hoja blanca virus (RHBV), but also because it causes mechanical damage through feeding and oviposition on its host plant. The use of chemical insecticides such as endosulfan, fenitrotion and fenucarb, which are highly toxic to mammals, is the most common control strategy against this pest
(Saunders et al. 1998). Therefore, alternative control measures should be developed.

One of such alternatives may be provided by the entomopathogenic bacterium Bacillus thuringiensis $(B t)$. During sporulation, Bt synthesizes crystalline parasporal inclusions composed of insecticidal proteins, known as $\delta$ endotoxins (Crickmore et al. 1998), which are innocuous to humans, friendly to the environment and the agroecosystem biodiversity and highly toxic and specific to certain insect pests. Based on the insecticidal activity of $B t$, commercial bioinsecticides have been developed 
for the control of lepidopteran, dipteran, and coleopteran larvae of economic importance (Glare and O'Callahan 2000). Additionally, the use of Bt genes to develop insect-resistant transgenic plants has proven to be highly effective, and may be an important alternative for the control of sucking insect pests, such as RDel.

Finding either a $B t$ toxin or any other toxin active against RDel, prospects should be subjected to extensive screening programs, where test individuals are exposed to a number of different toxic agents, under controlled bioassay conditions. These conditions must be previously standardized, in order to obtain repetitive, reliable results. Healthy individuals should be used in the bioassay and no more than $10 \%$ mortality should be allowed in the control population (Ibarra and Del Rincón 2001). Evaluation of gut poisons must rely on an effective feeding system that ensures the ingestion of sufficient dose, which is the bases for a reliable screening program of toxins (in coarse or qualitative bioassays), and also to determine dose-mortality relationships, directed towards the estimation of $\mathrm{LC}_{50} \mathrm{~s}$ (in quantitative bioassays) (Ibarra and Del Rincón 2001).

So far, no bioassay procedure has been published nor for RDel neither for any homopteran species, to test per os toxicity, in contrast to the abundant information available for lepidopteran, coleopteran, and dipteran larvae (McLaughling et al. 1984, Ibarra and Federici 1987, De León and Ibarra 1995). However, feeding systems for virus acquisition by homopteran species have been reported before (Espinoza 1989). These systems are based on the sucking of sugar solutions through Parafilm membranes that imitate, to some extent, the penetration of plant tissues and the sucking of sugar-rich content in phloem sieve elements, with high turgor pressure (Benrey and Lamp 1994).

In this report, we present the development of a procedure to establish a healthy and stable RDel colony that may provide enough test individuals for bioassays. Also, an in vitro feeding procedure was developed to test per os toxicity on RDel nymphs which showed natural mortality rates lower than $10 \%$. Finally, the toxicity of Bacillus thuringiensis strains, some of them isolated from homopterans, was evaluated using coarse bioassays. These procedures may provide a basis for a reliable screening program of $B$. thuringiensis toxins, or any other gut poisons.

\section{MATERIALS AND METHODS}

Field collection of $T$. orizicolus: native populations of RDel were collected in three rice growing regions of Costa Rica: Turrúcares, Tejar de Alajuela and Bagaces, using a D-Vac device (Craftsman $32 \mathrm{cc}$, USA), modified to trap the insects in a soft mesh cloth located between two extensions of the suction duct. Twelve transects were sampled on each field for four minutes per transect, on randomly selected zones, during the morning and in absence of rain. The collected material was transferred to plastic bags and then sorted out for RDel nymphs and adults in the laboratory. The selected insects were then transferred to sealed cages $(30$ X 40 X $40 \mathrm{~cm})$ covered with fine mesh, which contained four three-monthold rice plants each (cultivar CR-5272). Cages were kept at $80 \%$ relative humidity and temperatures ranging from $18{ }^{\circ} \mathrm{C}$ to $35^{\circ} \mathrm{C}$.

\section{Establishment of $T$. orizicolus colonies:} in order to eliminate any parasitoids, predators and entomopathogenic fungi coming along with field collections, insects were subjected to a quarantine period of two life cycles. Cages were monitored every other day to eliminate spiders, ants, beetles and parasitoids that could affect the progeny of $T$. orizicolus. Each cage contained a maximum of six four-month-old rice plants, growing in $250 \mathrm{ml}$ plastic pots with fertilized soil (1/3 Vermicompost and 2/3 rice bran). Pots were weeded weekly and old leaves were manually removed. Younger, more vigorous plants were introduced regularly to replace old plants. Plants were watered every other day and kept under field capacity. New 
colonies were established by taking 30 fourthor fifth-instar nymphs from the original cages, and transferred to $250 \mathrm{ml}$ pots containing four four-month-old plants covered by plastic cylinders with air openings sealed with fine mesh. These cages were kept for approximately 22 days until progeny was observed. When progeny reached the third instar, it was transferred to cages with the dimensions and conditions mentioned above.

Feeding assays: several approaches were tested to induce feeding of RDel nymphs on artificial solutions. All used fully stretched parafilm membranes to seal the different vials tested. First, Eppendorf tubes $(1.5 \mathrm{ml})$ were tested, by perforating three holes in the cap, filling the tube with sugar solution, and sealing the holes with parafilm. Each tube was then introduced in a cup with RDel nymphs. In a second trial, $10 \mathrm{ml}$ glass vials were tested. These were filled with $2 \mathrm{ml}$ sugar solution, sealed with Parafilm and inverted over a $20 \mathrm{ml}$ plastic cup, through an opening in the cover. Insects were introduced through an opening that was later sealed with cotton. Finally, $6 \mathrm{~cm}$ Petri dishes were tested. These were filled to the top with sugar solution and covered with Parafilm. Each Petri dish was then introduced into a larger dish (15 $\mathrm{cm}$ in diameter) with a filter paper on the bottom. Insects were then introduced using a mouth aspirator. Variants within each experimental assay included the use of 5,10 and 20 $\%$ sucrose solutions, previously autoclaved, as well as a 1:48 dilution of bee honey in sterile water. Also, the adaptability of different growth stages of $T$. orizicolus was evaluated in each feeding system, by recording mortality during a six day assay period. Mortality was recorded at the sixth day, according to previous observations where mortality stabilized at that point after a period of constant increase. The effect of perforating the Parafilm membranes with a $\mathrm{N}^{\circ}$ 0 dissection needle was also evaluated, as well as direct feeding on the sugar solution, without the use of Parafilm. For this purpose, twenty fourth-instar RDel nymphs were placed in a Petri dish, with droplets of sugar diet stained with a blue baking dye, to detect active feeding. Two to four bioassay replicates of all of these experiments were carried out in different days using an environmental chamber (White Westinghouse model 624) with a temperature of $18 \pm 0.1{ }^{\circ} \mathrm{C}$ at night and $28 \pm 0.1{ }^{\circ} \mathrm{C}$ during the day, $80 \%$ humidity and a $12: 12$ h photoperiod.

Effect of the colony origin on the natural mortality of $T$. orizicolus: RDel populations from Turrúcares, Tejar and Guanacaste were separately evaluated, in order to determine differential adaptability to the artificial feeding system. Populations were feed on $10 \%$ sucrose diets using the Petri dish feeding system. Each bioassay included six fourth-instar nymphs and four replicates per population. Mortality was recorded at the sixth day after the experiment started. Four of the bioassays were performed in a growth room where only the photoperiod $(12: 12 \mathrm{~h})$ and the luminosity (592 $\pm 2.76 \mathrm{lux})$ were controlled. The remaining bioassays were carried out in an environmental chamber under the conditions mentioned above.

Inoculum preparation for bioassays Bacillus thuringiensis strains: Bt israelensis (Bacillus Genetic Stock Center 4Q1), HD1, HD137 (provided by Daniel R. Zeigler), and the following native Costa Rican strains: 23-O-to, 26-O-To, 40-X-m and 43-S-d (all isolated from homopteran insects, isolation procedure in Mora-Castro 2003) were tested in coarse bioassays. Bt strains were inoculated on solid Agar-LB medium and incubated for approximately four days at $30^{\circ} \mathrm{C}$ until autolysis was reached.

Bioassays with Bacillus thuringiensis: in every coarse bioassay performed, 50 untreated insects distributed in three to four replicates were used as controls. The liquid diet used in the bioassays consisted of a 1:48 vol/vol dilution of bee honey in sterile water. Inocula of bioassays were made out of lyophilized spore-crystal complexes to make $1 \mathrm{mg} / \mathrm{ml}$ suspensions in a final volume of $9 \mathrm{ml}$. Primary powders were 
obtained by collecting fully autolyzed bacterial cultures from three Petri dishes, which were washed with sterile cold distilled water and centrifuged three times at $7000 \mathrm{rpm}$ for 30 $\mathrm{min}$ in a clinical centrifuge (IEC). Pellets were stored at $-20^{\circ} \mathrm{C}$ for $2 \mathrm{~h}$ and lyophilized (model LABCONCO, Lyph-Lock 12). Inoculated suspensions were placed into sterile $6 \mathrm{~cm}$ Petri dishes and covered by stretched Parafilm membranes, which were perforated 50 times using a sterile dissection needle $\left(\mathrm{N}^{\circ} 0\right)$. The sealed plate was then introduced into a larger Petri dish (10 $\mathrm{cm}$ in diameter) and insects were added using a mouth aspirator. All bioassays included three replicates per treatment and, according to insect availability, each treatment included between 20 and 30 third to fourth instar nymphs. A negative control was included in each bioassay, which contained only the honey solution. Bioassays were incubated in an environmental chamber (White Westinghouse, model 624) with temperatures set at $29 \pm 0.1{ }^{\circ} \mathrm{C}$ during the day and $19 \pm 0.1{ }^{\circ} \mathrm{C}$ at night, a relative humidity of $80 \%$ and $12: 12 \mathrm{~h}$ photoperiod. Percent mortality was determined at the sixth day and corrected using the Abbott's formula (Abbott 1925).

\section{RESULTS}

Establishment of $T$. orizicolus colonies: Colonies of T. orizicolus from Bagaces, Turrúcares and Tejar de Alajuela were established in the insectary. The colony from Bagaces started on May, 2001 and has been continuously maintained for about 11 generations. The colony from Tejar de Alajuela was established on August, 2001 and was maintained for about six generations, whereas the colony from Turrúcares was initiated one month later and was maintained for five generations. Quarantine of field collected insects was necessary as parasitism by Haplogonatopus hernandezae (Hymenoptera: Dryinidae) on nymphs and adult females was observed. Presence of assassin bugs (Hemiptera: Reduviidae), predators of immature stages and adults of T. orizi- colus, was also frequent. Both natural enemies were eliminated from the cages by manually removing adult predators and parasitized delphacids. After the quarantine period, colonies also suffered from predation by ants and by Cyrtorhinus lividipennis Reuter (Hemiptera: Miridae). Ants were eliminated from the rearing cages by immersing the supporting cage feet into soap water-filled containers, and by spreading boric acid near the cages. About $C$. lividipennis, seedlings coming from the greenhouse were apparently infested with this insect and manual removal from cages eventually was ineffective, as predation of RDel eggs was observed from newly emerged $C$. lividipennis nymphs. Exclusion of this insect from rearing cages was efficiently achieved by introducing the emerging seedlings in plastic cages. In addition, the fumagin fungus, although an indirect nuisance to the RDel colonies, was detected, but only in highly dense colonies.

Feeding assays: From the three feeding systems tested, the most successful was the Petri dish. In the Eppendorf tube system, no feeding behavior was observed at all, and test insects died in less than $24 \mathrm{~h}$. In the inverted tube system, occasional feeding was observed, with a mean survival of $48 \mathrm{~h}$. In the Petri dish system, frequent feeding was observed and most test insects survived for 14 days. In an attempt to increase the efficiency of this system, turgor pressure of the sugar solution within the Petri dish was increased by injecting a higher volume $(9 \mathrm{ml})$; resulting in an important decrease of RDel mortality. Optimal sucrose concentration $(5 \%, 10 \%$ or $20 \%)$ for the Petri dish feeding system was determined through a series of bioassays, using 12 thirdto fourth-instar nymphs per concentration and four replicates each $\left(X^{2}=15.223, p=0.000\right.$, d.f. $=3, \mathrm{~N}=120$ ). Mortality, recorded at the sixth day, indicated that the $10 \%$ sucrose solution showed the lowest rate (Fig. 1). Still, mortality was lower or equal to $10 \%$ in all the bioassays. Alternatively to the sucrose diet, a diluted bee honey solution was tested. Sucrose and honey treatments included four replicates, each 


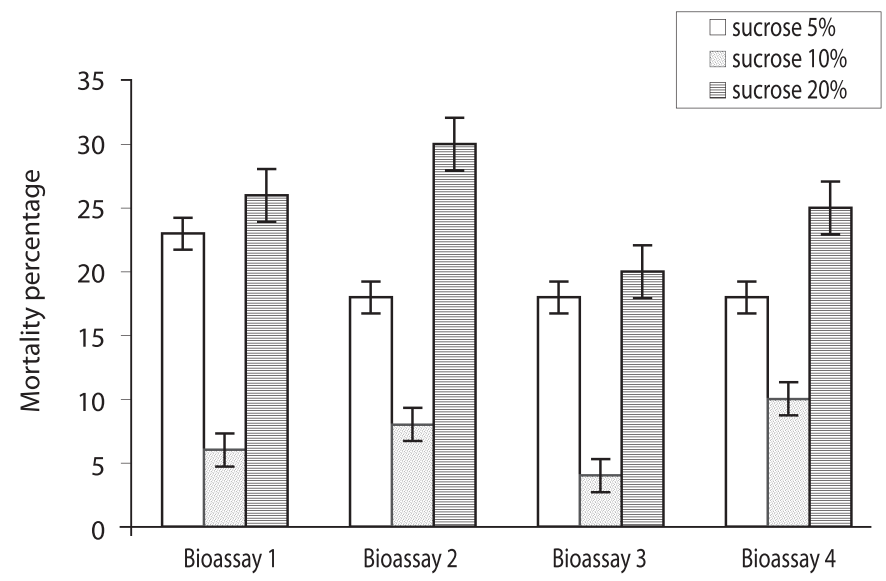

Fig. 1. Mortality percentage of $T$. orizicolus fifth instar nymphs at the sixth day of feeding on different concentrations of sucrose solutions through Parafilm membranes.

Fig. 1. Porcentaje de mortalidad de ninfas del quinto estadío de T. orizicolus al sexto día de alimentarse de diferentes soluciones de sacarosa a través de membranas de Parafilm.

with 20 third-to fourth-instar RDel nymphs. Mortality, recorded at the sixth day, indicated that three out of four replicates showed less that $5 \%$ mortality and the fourth replicate showed no mortality at all when diluted honey was tested, with an estimated mean percent mortality of $3 \pm 2 \%$ (Fig. 2). When sucrose solution was tested, two replicates showed $10 \%$ mortality, and the third and fourth replicates showed 12 and $15 \%$ mortality, respectively, estimating a mean percent mortality of $11.75 \pm 2.36$ $\%$ (Fig. 2). Additionally, sucrose solution was colored with a green cooking dye to test if this color produced any attraction to the insect into

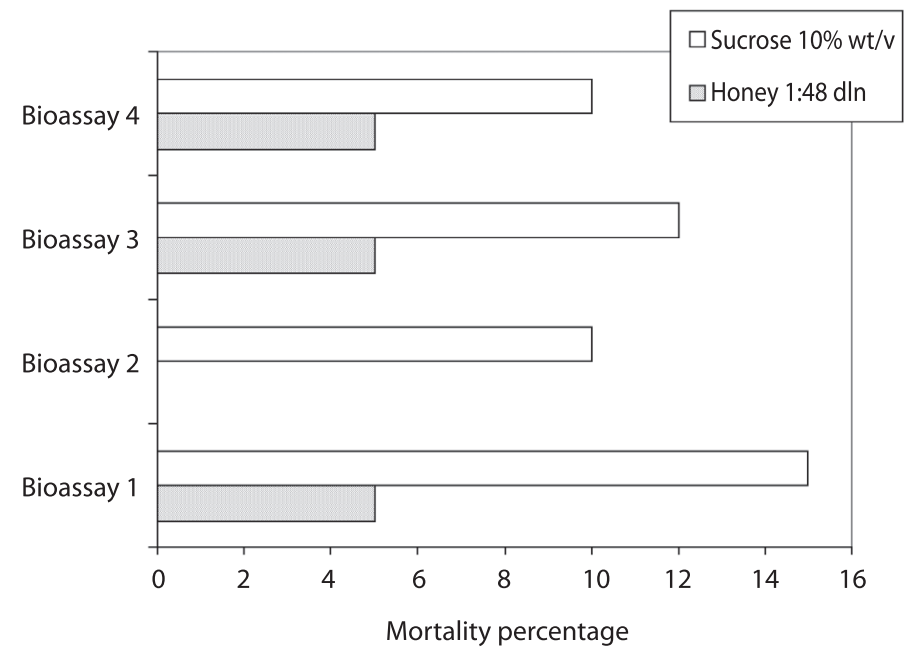

Fig. 2. Mortality percentage at 72 hours of T. orizicolus third and fourth instar nymphs after feeding on two types of liquid diet: $10 \%$ sucrose and diluted honey bee, through Parafilm membranes.

Fig. 2. Porcentaje de mortalidad a las 72 horas de ninfas de tercero a cuarto estadío de T. orizicolus después de alimentarse de dos tipos de dieta líquida: sacarosa al 10\% y miel de abeja diluida, a través de membranas de Parafilm. 
the feeding diet. No difference was observed between the colored and non-colored diets $\left(\mathrm{X}^{2}=2.857, \mathrm{p}=0.091\right.$, d.f. $\left.=1, \mathrm{~N}=60\right)$; however, fungal contamination was observed in the colored solution. Additionally, long-term bioassays were carried out, recording the mortality after 18 days. Both sucrose and honey solutions were tested on 15 third- to fourth-instar RDel nymphs per each of three replicates. Although similar, mortality was lower on insects fed with honey diet, especially during the first and the last three days of the bioassays. Still, by the $14^{\text {th }}$ and $15^{\text {th }}$ days, $50 \%$ mortality was observed in both treatments; however, less than $10 \%$ mortality was recorded during the first 12 days of the bioassays in both diets. To determine the optimal developmental stages of T. orizicolus for the bioassay, three different groups were tested: a) first- and second-instar nymphs, b) third- and fourth-instar nymphs, and c) fifth-instar nymphs (Fig. 3). Both, sucrose and honey diets were tested in two replicates, and mortality was recorded at the sixth day. Practically $100 \%$ mortality was recorded by the second day of the experiment, in both sucrose and honey diets, when first to second instars were tested. In contrast, third to fourth instars showed less that $10 \%$ mortality, whereas fifth instars showed mortalities below or equal to $10 \%$. That is, third to fourth instars showed the highest survival rate in the bioassays $\left(\mathrm{X}^{2}=76.312, \mathrm{p}=0.000\right.$, d.f. $=3, \mathrm{~N}=150)$. Noticeably, all the surviving nymphs from the last two groups became adults. Again, mortality was lower when honey diet was used $\left(\mathrm{X}^{2}=8.665, \mathrm{p}=0.003\right.$, d.f. $=1$, $\mathrm{N}=200$ ). Interestingly, when RDel nymphs were exposed to $10 \%$ sucrose droplets stained with blue dye (no Parafilm mediated), they survived approximately for one week, and feeding was corroborated by direct microscopic observations of the nymph blue abdomens. Based on this observation, Parafilm from the Petri dish feeding system was perforated with dissecting needles, decreasing significantly the RDel nymph mortality $\left(\mathrm{X}^{2}=13.636, \mathrm{p}=0.000\right.$, d.f. $=3, \mathrm{~N}=150$ ).

Effect of the colony origin on the natural mortality of T. orizicolus: The adaptability of three different RDel geographic populations to the artificial feeding system was evaluated

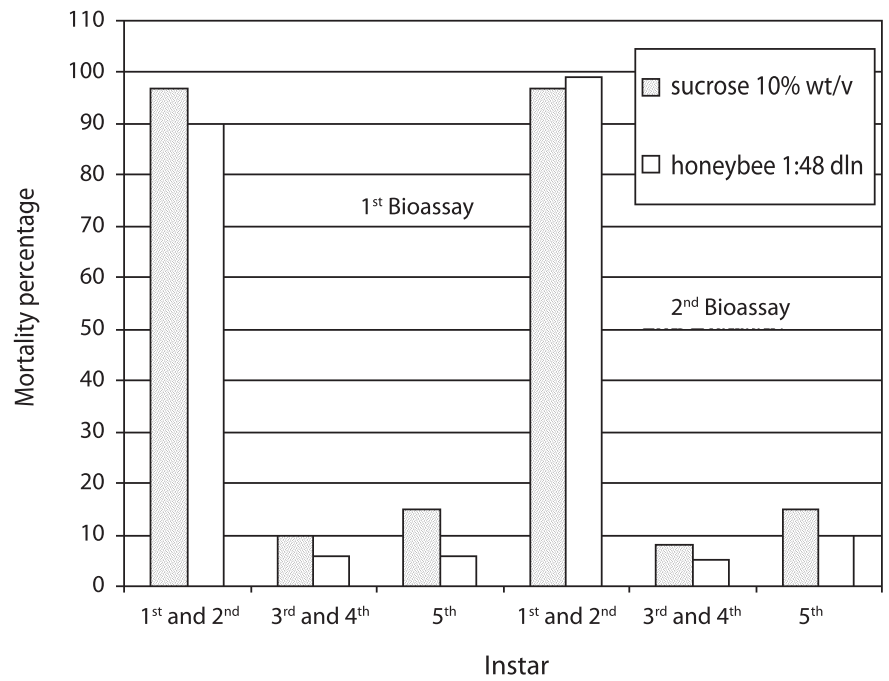

Fig. 3. Mortality percentage of $T$. orizicolus different instars after six days of feeding on two liquid diets: $10 \%$ sucrose and diluted honey bee, through Parafilm membranes.

Fig. 3. Porcentaje de mortalidad de los diferentes estadíos de T. orizicolus después de alimentarse por seis días de dos tipos de dieta: sacarosa al 10\% y miel de abeja diluida, a través de membranas de Parafilm. 
in six replicates. Figure 4 shows that natural mortality, after six days, was always close to 10 $\%$ and no significant difference was observed among populations. When the same series of bioassays were carried out without controlling temperature and humidity, the recorded mortality was much higher and variable among the populations.

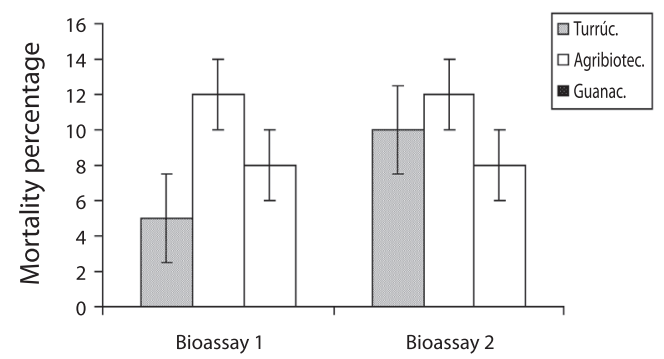

Fig. 4. Mortality percentage of T. orizicolus third and fourth instar nymphs from three Costa Rican rice producing regions after feeding for six days on a $10 \%$ sucrose diet through Parafilm membranes.

Fig. 4. Porcentaje de mortalidad de ninfas de tercero a cuarto estadío de $T$. orizicolus procedentes de tres zonas arroceras del país después de alimentarse por seis días de sacarosa al $10 \%$ a través de membranas de Parafilm.
Bioassays with Bacillus thuringiensis strains: Seven strains were evaluated in coarse bioassays using lyophilized spore-crystal complexes $(1 \mathrm{mg} / \mathrm{ml})$, the mortality was recorded at the sixth day of feeding in honey diet (Bioassay set up Fig. 5). Strains 26-Oto, 40-X-m, 43-S-d and 23-O-to, originally isolated from homopterans, showed RDel mortalities (mean of the mortality percentages of all three to four replicates) of 74, 96, 44 and $82 \%$ respectively while HD-137, HD-1 and Bt israelensis showed 19, 83 and $95 \%$ RDel mortalities, respectively (Table 1 ). The controls showed a mean natural mortality of $8.5 \pm 0.75 \%$ in the eight bioassays made.

\section{DISCUSSION}

Arearing system for T. orizicolus was developed under insectary conditions which allowed to maintain insect colonies for more than 12 generations and provided sufficient material to perform numerous bioassays. Furthermore, a feeding system through Parafilm membranes for nymphs of third to fourth instars was

TABLE 1

Mortality percentage of Tagosodes orizicolus third and fourth instar nymphs as a result of coarse bioassays using liofilized spores and crystals (1 $\mathrm{mg} / \mathrm{ml}$ solution) with eight strains of Bacillus thuringiensis

TABLA 1

Porcentaje de mortalidad de ninfas de tercer y cuarto estadio de Tagosodes orizicolus como resultado de bioensayos burdos utilizando esporas y cristales liofilizados (solución de $1 \mathrm{mg} / \mathrm{ml}$ ) de ocho cepas de Bacillus thuringiensis

Mortality percentage (\% in all table cells)

$\begin{array}{cccc}\text { Strains } & \begin{array}{c}(1 \mathrm{mg} / \mathrm{ml}) \text { liophilized } \\ \text { spores and crystals }\end{array} & \begin{array}{c}(1 \mathrm{mg} / \mathrm{ml}) \text { liophilized spores } \\ \text { and crystals Abbott formula }\end{array} & \begin{array}{c}\text { Negative } \\ \text { control }\end{array} \\ \text { 26-O-to } & 77 & 74 & 10 \\ 40-\mathrm{X}-\mathrm{m} & 97 & 96 & 8 \\ \text { HD137 } & 25 & 19 & 8 \\ \text { HD1 } & 84 & 83 & 8 \\ \text { Bti } & 96 & 95 & 8 \\ 43-\text { S-d } & 50 & 44 & 10 \\ \text { 23-O-to } & 84 & 82 & 8\end{array}$



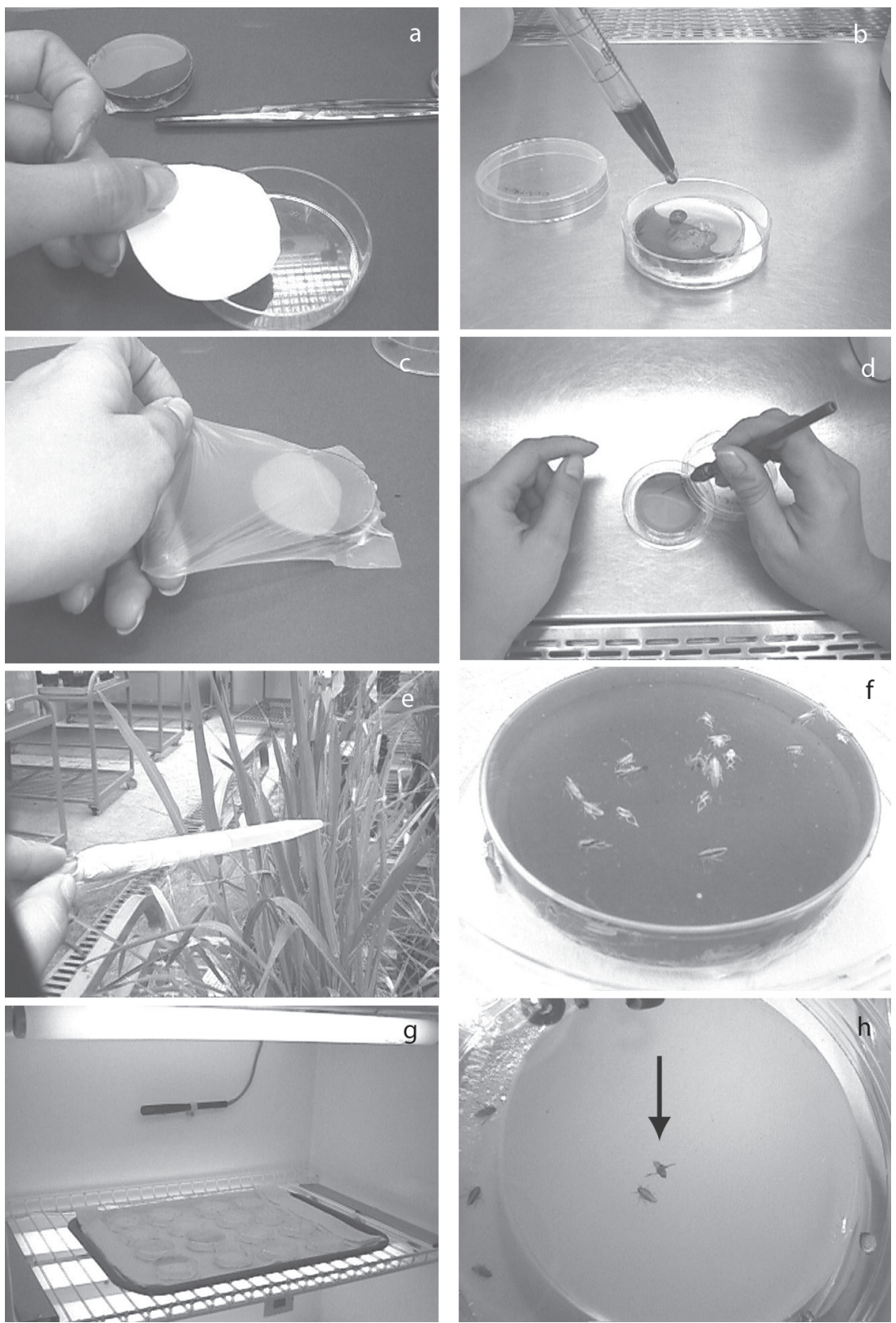

Fig. 5. Bioassay setup. A. A filter paper was introduced on the bottom of each Petri dish (15 cm in diameter). B and C. Each Petri dish was filled to the top with sugar solution and covered with Parafilm. D. The Parafilm membrane was perforated with a $\mathrm{N}^{\circ} 0$ dissection needle. $\mathrm{E}$ and $\mathrm{F}$. Insects were then introduced using a mouth aspirator. G. Two to four bioassay replicates of all the experiments were carried out using an environmental chamber H. Dead (arrow) and alive insects were recorded at the sixth day of feeding on the liquid diets.

Fig. 5. Montaje del bioensayo. A. Un papel filtro se introdujo en la base de cada plato Petri (15 cm de diámetro). B y C. Cada plato Petri se llenó con una solución azucarada y se cubrió con Parafilm. D. La membrana de Parafilm se perforó con una aguja $\mathrm{N}^{\circ} 0$ de disección. E and F. Los insectos se introdujeron con un aspirador manual. G. Réplicas de todos los bioensayos se llevaron a cabo en una cámara de crecimiento bajo condiciones controladas $\mathrm{H}$. Al sexto día se registraron los insectos muertos (flecha) y vivos en las diferentes dietas líquidas. 
established, using sucrose and honey bee solutions, in which the mortality was lower than 10 $\%$ for up to 12 days. In addition, no difference in the adaptability to insectary conditions was observed when insects from different localities of Costa Rica were used, under controlled conditions. Finally, RDel nymphs were subjected to coarse bioassays with $27 \mathrm{Bt}$ strains, using the feeding system previously established. Six strains presented major toxic effects toward $T$. orizicolus resulting in percent mortalities from 74 to $96 \%$.

Among the artificial feeding systems tested, the most successful proved to be the Petri dish filled with honey solution (1:48 vol/vol), covered with perforated Parafilm membranes. Other systems were significantly less efficient. According to the observations made during the series of tests, the success of the Petri dish system was apparently based on the availability of an extensive feeding surface and a more open environment (the larger Petri dish). Additionally, the use of filter paper in the bottom of the larger Petri dish facilitated the insect movement throughout the feeding system. Another positive addition was the perforations to the Parafilm membrane which may attract the insects towards the diet. Limited feeding surface and available space, as well as interference among individuals, tends to affect negatively their feeding behavior.

The increase of feeding on perforated Parafilm as well as the direct feeding of T. orizicolus on "open" sugar solutions (in absence of a membrane) may indicate that RDel actually feeds on nectar and water droplets in nature. It is important to remember that RDel is a monophagous species (Benrey and Lamp 1994) and that isolated rice fields are readily infested, suggesting that RDel may survive for extended periods only on nectar and other liquid food sources. Of course, hibernation as well as aestivation may also play a role in these particular situations.

It was obvious that, even if less than 10 $\%$ of natural mortality was achieved, artificial feeding on sugar or bee honey solutions affected the RDel normal development and behavior. Maintenance under such artificial conditions made the insects more susceptible to temperature and humidity stress. Mortality was higher and more variable when feeding tests were conducted under uncontrolled conditions, than when they were conducted in the environmental chamber.

The low mortality observed in the controls of the coarse bioassays indicates that any increase in mortality above ten percent, is due to the toxic effect of $B t$ crystal proteins or to a synergistic effect of spore and crystal proteins. However, the latter should be examined in fine bioassays using purified crystals. It is important to mention that, in order to eliminate any putative toxic effect of the $\beta$-exotoxin (as it may be present in some of these strains) in coarse bioassays, spore and crystal suspensions were thoroughly washed by centrifugation before incorporating them into the diet. This report shows that the strains $40-\mathrm{X}-\mathrm{m}$ and HD1, that contain cry1Aa, cryIAb, cryIAc and cryIAd genes (Mora and Espinoza 2004) showed mortalities above $80 \%$.

It is also important to mention that RDel mortality close to $100 \%$ was observed with the Bti strain. This previous result shows that a dipteran (mosquitocidal) (Chilcott et al. 1983) and coleopteran (H. hampei) toxic strain (Méndez-López et al. 2003) was also effective against $T$. orizicolus. This toxicity may be due to the effect of one or several toxic proteins contained in this strain: Cry4A, Cry4B, Cry 10A, Cry 11A, Cyt1A and Cyt2A (Crickmore et al. 1995).

It is important to mention that, due to the sucking feeding habit of $T$. orizicolus, natural interactions with $B t$ are unknown. Therefore, processing of the $B t$ protoxin within the homopteran digestive tract may be difficult to efficiently process the crystal, so dissolved and tripsinized toxins should be considered for future bioassays. Also, crystal proteins may be efficiently processed by RDel digestive tract, but higher concentrations may be needed due to the fact that homopterans ingest and rapidly excrete large volumes of their liquid diet, reducing the midgut residence of toxins (Walters and English 1995). 
Natural interaction between $B t$ and sapsucking insects may be uncertain, as they feed directly from the inner plant tissues (mostly phloem). Sporadic intake of nectar or other liquid sources from the plant surface may explain occasional Bt ingestion in nature. However, finding $B t$ toxins active against sap-sucking insects not necessarily implies that $B t$ is a natural pathogen for these insects. The overwhelming majority of natural $B t$ strains have been isolated from non-insect sources (Glare and Callaghan 2000). Furthermore, many $B t$ strains have been isolated from dead insects without being the cause of their death (Chilcott and Wigley 1993, Iriarte et al. 1998, Panizzi and Pinzauti 1988), and some of these strains have even shown activity against insects of different order to those where they were isolated from (De León and Ibarra 1995, Méndez-López et al. 2003). That is one of the reasons why considering $B t$ a "true" insect pathogen is still a matter of discussion.

In continuation to this work, further strain screening is planned, as well as the implementation of fine bioassays to estimate $\mathrm{LC}_{50} \mathrm{~s}$ of those strains found active in coarse bioassays: 26-O-to, 40-X-m, 23-O-to, HD1 and Bti. Also, the test of individual Cry proteins is included in future work, provided that their cry genes are previously cloned and expressed individually. This type of tests may also lead to the search for putative synergistic relationships between the Cry proteins, as it has been established before (Tabashnik 1992).

The discovery of toxic $B t$ strains active against $T$. orizicolus is important, as it opens the possibility of conducting basic studies that may help understand the interaction of $B t$ $\delta$-endotoxins with the gut of phloem-feeding insects. It may also provide an environment friendly alternative for the control of this important insect, as Cry genes may be used for the genetic transformation of rice, including the possibility of plastid transformation which dramatically enhances the level of protein expression (Daniell et al. 2002). This strategy does not exclude the use of other biological control methods, such as the use of RDel parasitoids and the conservation of natural enemies, which are important controlling agents of $T$. orizicolus populations.

\section{RESUMEN}

Se desarrolló una metodología de bioensayo para evaluar toxinas de Bacillus thuringiensis (Bt) ingeridas por Tagosodes orizicolus, plaga del arroz y vector del virus de la hoja blanca. Se establecieron colonias del insecto en condiciones de invernadero usando plantas de arroz como alimento. Para el bioensayo, se desarrolló un sistema de alimentación in vitro para ninfas de tercer y cuarto estadío. Los insectos se alimentaron de soluciones de miel de abeja $(1: 48 \mathrm{vol} / \mathrm{vol})$ y sacarosa $(10 \%)$ a través de membranas de Parafilm. Se observaron mortalidades del $10-15 \%$ y $0-5$ $\%$, respectivamente, en ambas dietas. Los resultados fueron reproducibles en condiciones controladas de humedad y temperatura $\left(18 \pm 0.1{ }^{\circ} \mathrm{C}\right.$ de noche y $28 \pm 0.1{ }^{\circ} \mathrm{C}$ de día, $80 \%$ H.R y a 12:12 fotoperíodo día:noche). Asimismo, se analizó la mortalidad natural de los insectos según su procedencia, sin embargo, no se observaron diferencias significativas en condiciones controladas. Finalmente, se elaboraron bioensayos para evaluar la toxicidad de una colección de cepas de Bt contra T. orizicolus. Se evaluó preliminarmente, una submuestra de 27 cepas de $B t$ en bioensayos burdos usando tres asadas como inóculo para $9 \mathrm{ml}$ de dieta líquida. Posteriormente, las cepas que mostraron los mayores porcentajes de mortalidad se evaluaron en bioensayos usando esporas y cristales liofilizados (1 $\mathrm{mg} / \mathrm{ml}$ ). Como resultado, las cepas aisladas a partir de homópteros 26-O-to, 40-X-m, 43-S-d y 23-O-to mostraron mortalidades de $74,96,44$ y $82 \%$ respectivamente, mientras que las HD-137, HD-1 y Bti mostraron 19, 83 y 95 $\%$ de mortalidad. Los controles presentaron mortalidades de 0 y $10 \%$ en los bioensayos. Este es el primer informe de un bioensayo para evaluar la toxicidad de cepas de $B t$ utilizando la especie T. orizicolus.

Palabras clave: Tagosodes orizicolus, Homoptera, delfácido del arroz, bioensayo, cría, dieta azucarada, Bacillus thuringiensis, $\delta$-endotoxinas.

\section{REFERENCES}

Abbott, W.S. 1925. A method of computing the effectiveness of an insecticide. J. Econ. Entomol. 18: 265267.

Benrey, B. \& W.O. Lamp. 1994. Biological control in the management of planthopper populations, p. 519-549. In R.F. Denno \& C.J. Perfect (eds.). Planthoppers, their ecology and management. Chapman and Hall, New York, New York, USA. 
Chilcott, C.N. \& P.J. Wigley. 1993. Isolation and toxicity of Bacillus thuringiensis from soil and insect habitats in New Zealand. J. Inverterb. Pathol. 61: 244-247.

Chilcott, C.N., J.S. Pillai \& J. Kalmakoff. 1983. Efficacy of Bacillus thuringiensis var. israelensis as a biocontrol agent against larvae of Simuliidae (Diptera) in New Zealand. New Zeal. J. Zool. 10: 319-325.

Crickmore, N., D.H. Dean, J. Feitelson, J. Lereclus, E.J. Schnepf, D. Van Rie \& D.R. Zeigler. 1998. Revision of the nomenclature of Bacillus thuringiensis pesticidal crystal proteins. Microbiol. Molec. Rev. 62: 807-813.

Crickmore, N., D.R. Zeigler, J. Feitelson, A. Schnepf, B. Lambert, D. Lereclus, J. Baum \& D.H. Dean. 1995. Revision of the nomenclature for Bacillus thuringiensis pesticide cry genes, p. 14. In Program and Abstracts of the 28th Annual Meeting of the Society for Invertebrate Pathology. Society for Invertebrate Pathology, Bethesda, Maryland, USA.

Daniell H., S. Muhammad \& L. Allison. 2002. Milestones in chloroplast genetic engineering: an environmentally friendly era in biotechnology. Tr. Plant Sci. Vol 7, No. 2 .

De León, T. \& J.E. Ibarra. 1995. An Alternative Bioassay Technique to Measure Activity of Cry III Proteins of Bacillus thuringiensis. J. Econ.c Entom. 88: 1 596-1 601 .

Espinoza, A.M. 1989. Studies on the aphid transmission factor of cauliflower mosaic virus. Ph. D. Thesis, University of East Anglia, Norwich, England. 124 p.

Glare, T. \& M. Callaghan. 2000. Bacillus thuringiensis: Biology, Ecology and Safety. Wiley, New York, New York, USA.

Ibarra, J.E. \& B.A. Federici. 1987. An alternative bioassay employing neonate larvae for determining the toxicity of suspended particles to mosquitoes. J. Am. Mosq. Control Ass. 3: 187-192.

Ibarra, J.E. \& M.C. Del Rincón-Castro. 2001. Cuantificación Toxicológica de Bacillus thuringiensis, p. 133-152. In P. Caballero \& J. Ferré (eds.). Bioinsecticidas:
Fundamentos y Aplicaciones de Bacillus thuringiensis en el Control Integrado de Plagas. M.V. PhytomaEspaña, S.L. Valencia, España.

Iriarte, J., Y. Bel, M.D. Ferrendi, R. Andrew, J. Murillo, J. Ferré \& P. Caballero. 1998. Environmental distribution and diversity of Bacillus thuringiensis in Spain. Syst. Appl. Microbiol. 21: 97-106.

McLaughling, R.E., R.T.L. Alls, D.A. Couch, I.M Dame., H.T. Dulmage, R.I. Hall \& P.L. Versoi. 1984. U.S. standard bioassay for the potency assessment of Bacillus thuringiensis serotype $\mathrm{H}-14$ against mosquito larvae. Bull. Entomol. Soc. Am. 30: 26-29.

Méndez-López, I., R. Basurto-Ríos \& J.E. Ibarra. 2003. Bacillus thuringiensis serovar israelensis is highly toxic to the cofee berry borer, Hypothenemus hampei Ferr. (Coleoptera:Scolytidae). FEMS Microb. Lett. 11 131: 1-5.

Mora-Castro, R. 2003. Caracterización molecular de una colección de cepas de Bacillus thuringiensis e implementación de un sistema novedoso de bioensayo para evaluar su efecto tóxico contra la plaga del arroz, Tagosodes orizicolus (Homoptera: Delphacidae Muir). Tesis de maestría, Universidad de Costa Rica, San José, Costa Rica. 120 p.

Panizzi, L. \& M. Oinzauti. 1988. Proliferation of pathogenic bacteria in the nest of the Apis mellifera following attack by Varroa jacobsoni Oud. Apiacta 23: 74-78.

Porcar, M. \& V. Juárez-Pérez. 2003. PCR-based identification of Bacillus thuringiensis pesticidal cristal genes. FEMS Microbiol. Rev. 26: 419-432.

Saunders, J., D. Coto \& A. Kin. 1998. Plagas invertebradas de cultivos anuales alimentarios de América Central. Manual ténico No. 29. CATIE. Turrialba, Costa Rica.

Tabashnik, E.B. 1992. Evaluation of Synergism among Bacillus thuringiensis Toxins. App. Env. Microb. 58: 3 343-3 346.

Walters, F. \& L. English. 1995. Toxicity of Bacillus thuringiensis delta-endotoxins toward the potato aphid in an artificial diet bioassay. Entom. Exp. App. 77: 211-216. 
